\title{
The Effect of Administrative Control on Improving the Quality of Health Services: An Empirical Study on Al- Awda Hospital
}

\author{
Mansour M. ALAYOUBI ${ }^{1}$, Zakieh M. AREKAT ${ }^{2}$, Mazen J. AI SHOBAKI ${ }^{3}$, Samy S. ABU-NASER ${ }^{*}$
}

\author{
${ }^{1}$ Palestine Technical College- Deir al-Balah, Gaza- Palestine, Email: mansour.alayoubi1970@gmail.com \\ ${ }^{2}$ Arab University College of Technology, Email: zakieharekat@gmail.com \\ ${ }^{3}$ Faculty of Administrative and Financial Sciences, Israa University - Gaza- Palestine, \\ Email: mazen.alshobaki@gmail.com \\ ${ }^{4}$ Faculty of Engineering and Information Technology, Al-Azhar University, Gaza, Palestine, \\ Email: abunaser@alazhar.edu.ps \\ * Corresponding Author
}

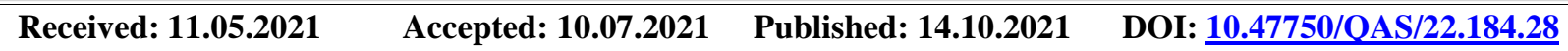

\begin{abstract}
This study aimed to identify the impact of administrative control in improving the quality of health services in Al-Awda Hospital in North Gaza Governorate. The researchers used the descriptive analytical method. The study population was selected from all employees in administrative and nursing jobs, that constitute (60) male and female employees in the hospital. The researchers used the comprehensive inventory method for all members of the study population; Due to the small size of the study population, a questionnaire was used to collect the data. The study reached a set of results, the most important of which are: The level of the respondents' answers in Al-Awda Hospital about administrative control was to a large degree (83.60\%), and about the quality of health services was significantly (80.20\%), and there is also a direct statistically significant relationship between the dimensions of control. Administrative control and improving the quality of health services in Al-Awda Hospital, where the correlation coefficient was (0.509), and the results showed a statistically significant effect between the dimensions of administrative control on the quality of health services. The study recommended that the hospital's senior management should pay attention to all dimensions of administrative control, and the elements that contribute to improving the quality of health services, the results of which showed their importance and impact on improving the quality of health services in the hospital.
\end{abstract}

Keywords: Administrative Control, Quality of Health Services, Al-Awda Hospital, Gaza strip, Palestine.

\section{Introduction}

The concept of administrative control has received great and wide attention, as interest has increased in light of global developments and some crises witnessed by business organizations. The most important of which were the weakness of management, the absence of the supervisory role, the deterioration in the services provided to beneficiaries, and the spread of administrative and financial corruption. From the work of the organization with the aim of facilitating access to the strategic goals of the organization.

Quality is an important indicator in various aspects of the practical life of organizations and an essential element in production processes, whether services or goods, and it is a strategic tool in all organizations that constantly strive to achieve sustainable quality, increase productivity and improve performance. As for quality in health services, it is an important issue for the health and safety of all community members, as the quality of health services worldwide is the most important quality indicator in the lives of countries, as lack of hygiene and long waiting times are among the main reasons today to avoid government health organizations, in addition to that most hospitals do not provide the necessary conditions to improve safety and security (Al-Saadi and Al-Rubaie, 2021: 159).

Many business organizations seek to improve their performance and achieve excellence in their services in various ways and in various sectors, including the non-governmental health services sector, in order to keep pace with the rapid technological progress, and to prove their ability to survive, grow and continue in light of the existing severe competition, and in order to achieve ambitions Citizens in terms of their access to health services with the utmost speed, accuracy, quality and competitive prices (Al-Otaibi, 2014, pp. 1-2).

Based on this, the researchers wanted to conduct a study on the impact of administrative control in improving the quality of health services in Al-Awda Hospital in North Gaza Governorate, because many hospitals seek to achieve excellence in the performance of their health services and maintain the lead in their Domain of work, in order to raise this sector to the ranks of sectors global health. 


\section{Research Terminology}

For the purposes of the study, the following terms were defined:

- Administrative Control: the activity carried out by the administration to follow up and evaluate the implementation of objective policies and work to fix any weaknesses it may encounter in order to reach the desired goals (Hamza, 2013: 140).

- Quality of Health Services: services provided to individuals or communities by health service providers for the purpose of promoting, maintaining, monitoring or restoring health (D'Cunha \& Suresh, 2015: 334).

- Al-Awda Hospital: Al-Awda Hospital is the largest health facility affiliated with the Union of Health Work Committees. It was established in the year 1992. It was opened in April 1997 with a capacity of 53 beds and with the contributions of the local community, amounting to more than $(75 \%)$ of the construction cost, which is a source of pride. For every Palestinian, the number of beneficiaries for the year (2016) reached about $(15,084$ beneficiaries), with an increase in the number of beneficiaries/s by (15.3\%) compared to the year (2015). As a result of the expansion in Al-Awda Hospital, the number of beds became (77) with the possibility of expansion in emergency cases, bringing the number of beds to (100) beds (https://gaza-health.com), the date of which was accessed on 23/4/2021.

\section{Problem Statement}

Most of the local health organizations in the governorates of Gaza lack an applied methodology in their work. Therefore, these organizations need to implement a mechanism that contributes to improving the quality of the health service and achieving patient satisfaction and expectations, especially waiting times, service delivery times, and hygiene, which is an important indicator for achieving patient satisfaction, as Health organizations, including Al-Awda Hospital in Gaza Governorate, suffer from a lack of funding to cover the total costs and a significant shortage of qualified and trained human resources from the category of doctors with specializations such as: neonatology, emergency medicine, and intensive care medicine, and a shortage in the nursing category, and there is also weakness In some types of medicines and medical supplies, which negatively affects the provision of the health service, and there is a weakness in the legislative and legal system related to the principles of medical responsibility and accountability, in addition to the poor work environment and the lack of standardized procedures and methods, as patients suffer from long waits and lack of speed in responding to their requirements, as well as There are many obstacles that affect the provision of health service quality, such as: the high number of Gaza patients referred to health care in Al-Awda Hospital, and a significant shortage of medical supplies. Hospitals' medical needs, the decline in the number of hospital beds, and the absence of a clear policy for optimal disposal of medical waste despite the presence of some limited experiences in the hospital, and there is a weakness in the system of supportive administrative services such as: (cleaning services, laundry services, and food services).

The war on Gaza in (2014) and (2021) led to the damage and closure of a large number of hospitals, including Al-Awda Hospital. Since April (2017), the Gaza Strip has faced an aggravation of the electricity crisis, as the electricity is only available for a period of (4-6) Hours a day after the measures taken by the Palestinian Authority, the electricity supply from
Israel, the hospital administration was forced to postpone some surgeries, prematurely discharge patients, and reduce cleaning and sterilization services.

The administration of Al-Awda Hospital in North Gaza Governorate seeks to maintain a distinguished level of health service that it provides to all segments of patients, and given the harsh conditions experienced by the hospitals of Gaza Strip in general and Al-Awda Hospital in particular, they have arranged a high level of various pressures on citizens, the administration of Al-Awda Hospital is concerned with reducing work pressure Internal affairs related to the nature of tasks and roles performed by hospital staff in order to maintain a good level of focus in performance

The need for Al-Awda Hospital in particular to excel in the performance of its health services and maintain its continuity in a competitive environment has become an urgent need for survival and growth, and administrative control is one of the important variables that have an effective and essential role in the success of the hospital in improving the quality of services provided to patients.

\section{Research Questions}

The main question: What is the effect of administrative control on improving the quality of health services in Al-Awda Hospital in North Gaza Governorate from the point of view of employees?

Several sub-questions emerge from the main question:

Q1-: What is the reality of administrative control in Al-Awda Hospital in North Gaza Governorate?

Q2-: What is the level of quality of health services in Al-Awda Hospital in North Gaza Governorate?

Q3-: Is there a correlation between administrative control and the quality of health services in Al-Awda Hospital in North Gaza Governorate?

Q4-: Determining the impact of the dimensions of administrative control on the quality of health services in AlAwda Hospital in North Gaza Governorate?

\section{Research Objectives}

This study aims to achieve the following objectives:

1. Identifying the reality of administrative control in AlAwda Hospital in North Gaza Governorate.

2. Indicating the level of quality of health services in AlAwda Hospital in North Gaza Governorate.

3. Revealing the nature of the relationship between administrative control and the quality of health services in Al-Awda Hospital, North Gaza Governorate.

4. Determining the impact of the dimensions of administrative control and the quality of health services in Al-Awda Hospital in North Gaza Governorate.

5. Presenting a set of recommendations that help the senior management at Al-Awda Hospital to develop and activate administrative control mechanisms, which contribute to improving the quality of health services provided to patients.

\section{Research Importance}

The importance of the study is shown by the benefit that will be given to:

Scientific (Theoretical) Importance:

1. This study sheds light on one of the entrances to modern administrative thought, which is the impact of administrative control on improving the quality of health 
services in the reality of our Palestinian institutions.

2. This study is useful and provides researchers and scholars with data and information in the Domain of administrative control and the quality of health services through its findings and recommendations that may contribute to alleviating the negative effects of the quality of health services provided to patients.

Practical (Applied) Importance:

1. The importance of this study lies in the extent to which the recommendations it came out with have been achieved and applied, which may benefit the administration of Al-Awda Hospital in particular and other similar hospitals in general.

2. It is possible that the current study will provide the higher departments and responsible authorities in AlAwda Hospital with information about the importance of paying attention to administrative control, which in turn may contribute to improving the quality of health services provided to patients, and extracting the latent energies of hospital workers, which in turn is reflected in achieving the general benefit of the hospital and progress and competition in The health and administrative Domain, as well as better performing their duties and services towards society.

\section{Research hypothesis}

The study seeks to test the validity of the following hypotheses:

Ho1: There is a statistically significant relationship at the level of significance $(\alpha \leq 0.05)$ between the dimensions of administrative control (Organizational Structure, Performance Evaluation, Control Tools and Means, Requirements to Achieve the Effectiveness of Administrative Control) and improving the quality of health services in Al-Awda Hospital.

Ho2: There is a statistically significant effect at the level of significance $(\alpha \leq 0.05)$ for the dimensions of administrative control (organizational structure, performance evaluation, monitoring tools and means, requirements to achieve the effectiveness of administrative control) on improving the quality of health services in Al-Awda Hospital.

\section{Research Limits and Scope}

The scope of the study shall be as follows:

1. Objective Limit: The research was limited to studying the impact of administrative control in improving the quality of health services, and the researchers relied on the dimensions of administrative control from the study (Abu Salmi and Abbas, 2016; Omar (2014) namely (organizational structure, performance evaluation, tools and control tools, requirements to achieve the effectiveness of administrative control). As for the dimensions of health service quality, the dimensions were adopted from the study (Dora et all. 2018; Sedky and Hamoudi, 2016) which are (tangibility, dependability, responsiveness, empathy, safety).

2. Human Limit: The study is limited to surveying the opinions of administrative and nursing staff, mainly in Al-Awda Hospital.

3. Spatial Limitation: The study was conducted on AlAwda Hospital in Gaza Strip.

\section{Previous Studies}

$>$ Study of (Al-Saadi and Al-Rubaie, 2021), which aimed to identify the effect of the 5S methodology in improving the quality of health service at Imam Hussein Teaching Hospital in Dhi Qar from the point of view of doctors and medical staff. The study used the descriptive analytical approach, and a random sample was selected It consists of (147) doctors and medical staff in the Consultation Department, the Emergency Division and the Medical Supplies Division at Al-Hussein Teaching Hospital in Dhi Qar. The questionnaire was used as a data collection tool. The study reached several results, the most important of which are: There is moderate agreement by the respondents on the level of health service quality. In the surveyed hospital, the relative weight was (62.8\%). There is a correlation and effect between the $5 \mathrm{~S}$ methodology and its dimensions and improving the quality of health service.

$>$ Study of (Mohamed, 2019) which aimed to identify the impact of control on performance and improve the quality of health care services in Shubra General Hospital (Kitchener) in Egypt, and the study used the descriptive analytical approach, and a random sample consisting of (282) employees was selected from the hospital The questionnaire was used as a data collection tool, and the study reached several results, the most important of which are: there is a large approval by the respondents on the level of control in Shubra General Hospital, and there is a large approval by the respondents on the level of quality of health care services in Al-Bashir Hospital, and there is a significant relationship Statistics to monitor improving the quality of health care services in Shubra Hospital.

$>$ Study of (Bergerum, et al, 2019) which aimed to identify the possible mechanisms that contribute to the success or failure of effective patient participation in improving health service quality, in addition to clarifying the most important main considerations for organizing and supporting patient participation in health care improvement efforts. The descriptive analytical approach, and to achieve the objectives of the study, the researchers presented (1024) articles in health care with a focus on improvement efforts that included patients, care professionals or leaders, and the study reached several results, the most important of which are: The active participation of the patient is a performance designed to interact, and leads to Behavior change in the development of the health service, in addition to the fact that health care organizations have taken an approach to involve the patient at different levels in health care institutions to be successful in decision-making.

$>$ Study of (Manzi, et al, 2019) that aimed to enhance the performance of health care providers in (21) health centers in rural Razanda, where researchers measured the completeness of risk markers operations by expert nurse counselors working through standardized checklists as a primary measure, and found The study resulted in several results, the most important of which are: improving the assessment for collecting danger signs from $(2.1 \%)$ to $(84.2 \%)$, controlling the nurses' assessment level, improving the quality of care after traditional training, and improving the assessment of medical history, including previous surgeries, and current medications.

> Study of (Dora et all.,, 2018), which aimed to assess the level of quality of health services provided in the Oman health sector from the point of view of patients, through a comparison between government hospitals and private hospitals in the Governorate of Dafar. The study used the descriptive analytical approach, and a sample was 
chosen. Randomly consisting of (360) respondents from patients who received health services in four public and private hospitals, and the questionnaire was used as a tool for data collection, and the study reached several results, the most important of which are: There is a medium degree of approval by the respondents regarding the level of health service quality in the surveyed hospitals, where it reached Relative weight $(65.4 \%)$. There are statistically significant differences between males and females in favor of females in terms of the level of quality of health services provided, and there are no statistically significant differences between the study sample according to the variables of age and educational qualification.

> Study of (Sedky and Hamoudi, 2017), which aimed to measure the quality of health service provided in Aleppo governmental hospitals, and the study used the descriptive analytical method, and a random sample consisting of (174) individuals working in four hospitals was selected: (Al-Razi Hospital, Ibn Rushd Hospital Aleppo University Hospital, University Obstetrics and Gynecology Hospital) and from three specialties: doctors, nurses, and administrators. The questionnaire was used as a data collection tool. The study reached several results, the most important of which are: There is a medium degree of approval by the respondents regarding the level of health service quality in the surveyed hospitals. , where the relative weight was $(75 \%)$. There are statistically significant differences between service providers in Aleppo governmental hospitals due to the following demographic variables: (gender, age, and years of service).

$>$ Study of (Abu Salmi and Abbas, 2016) which aimed to identify the extent of the timely application of administrative control and its impact on improving the quality of performance in the health sector in Jordan. The study used the descriptive analytical approach, and a simple random sample was selected consisting of (150) employees. In Zarqa Hospital, the questionnaire was used as a data collection tool, and the study reached several results, the most important of which are: The availability of the basic components of control greatly enhances the effectiveness of internal control systems in the health sector in Jordan, and there is a statistically significant effect of administrative control in improving the quality of hospital performance Zarqa Governmental.

Study of (Omar, 2014) which aimed to identify the impact of administrative control systems on improving the quality of health services in Al-Bashir Hospital. The study used the descriptive analytical approach, and a random sample consisting of (136) individuals working in administrative, medical and nursing units was selected, and a questionnaire was used. A tool for data collection, and the study reached several results, the most important of which are: There is a medium degree of approval by the respondents on the level of administrative control systems in Al-Bashir Hospital, where the relative weight reached $(59.49 \%)$, and there is a medium degree of approval by the respondents regarding the quality of health services in the Hospital AlBashir, where the relative weight reached $(51.1 \%)$, and there is a statistically humiliating effect of the dimensions of administrative control systems on improving the quality of health services in Al-Bashir Hospital.

$>$ Study of (Shuichi, 2014) that aimed to identify the role of middle management, including the head of the nursing department and chief physician, in applying administrative control in hospitals in the Japanese city of
Tokyo. The study sample consisted of health care workers, and the study reached several results, the most important of which are: The participation of middle management in oversight leads to many benefits for their role in influencing employees positively, continuous communication with them, and their ability to influence senior management, which reduces conflict between employees and the hospital, and thus leads to achieving job satisfaction for employees, and helps achieve direct interaction between employees. And management to maintain the services and to achieve control over the various activities between the middle and lower management levels in the hospital.

$>$ Study of (Snowdon and Karin, 2012), which aimed to identify the measurement of the performance and efficiency of the health system in Canada and its financing methods, and the problem of the study was the extent to which the values of health care in Canada are applied according to the standards of the Organization for Economic Cooperation and Development (OECD), and the study used the descriptive, analytical and methodological approach. The study found several results, the most important of which are: OECD countries tend to focus more on a healthy life, Canada occupies a lagging position in increasing health system costs compared to OECD countries, and relies heavily on hospital care.

\subsection{Commenting on Previous Studies}

By analyzing the previous studies, it becomes clear to us that:

1. Most of the previous studies dealt with by researchers are recent studies between the years 2012-2021 AD.

2. The study agreed with previous studies in using the descriptive approach as a study method, such as: (AlSaadi and Al-Rubaie, 2021), (Manzi, et al, 2019, 2018), and (Dora et all, 2019). This is due to its relevance to the subject of the study, and the current study agreed with most of the previous studies in its use of the questionnaire as a tool for the study.

3. The places of application of previous studies varied, including Arabic studies (Iraq, Jordan, Syria, and Oman) as a study (Sedky and Hamoudi, 2017), a study (Abu Salmi and Abbas, 2016), and a study (Omar, 2014), including foreign studies as a study (Bergerum, et al, 2019), and a study (Shuichi, 2014).

4. Previous studies were made use of in defining the study problem, in defining study variables, hypotheses, and study tools, and in strengthening the results of the current study with previous studies and comparing them with them.

5. The current study is distinguished from previous studies in that it was applied to a non-governmental hospital, AlAwda Hospital in North Gaza Governorate, and it is one of the few studies - to the knowledge of the researchers - that are being conducted in the Palestinian society, and it mainly focuses on studying the impact of administrative control on improving the quality of health services.

\section{Theoretical Framework}

\section{First: Internal Control}

The concept of administrative control has not changed since antiquity, despite the development of information and communication technology systems and their uses in the Domains of management, finance, accounting, production and 
control in all its stages and others, but what has changed is the traditional control tools and the way decisions are taken and errors and deviations in work are corrected first hand.

\section{The Concept of Management Control}

Many scholars and specialists have endeavored to develop a specific definition of administrative control, which he defined (Al-Zaher, 2010: 302) as: "An administrative function and a continuous, renewable process by which performance is verified as defined by the objectives and established standards, by measuring the degree of performance success. The actual achievement of goals and standards for the purpose of evaluation and correction. As defined by (Derry, 2011: 13) as: "The process of measuring results and comparing them with plans or standards, diagnosing the reasons for deviation of actual results from the desired results, and taking corrective measures when that is necessary." (Al-Anazi, 2014: 9) defined it as" The process of directing the activities of individuals towards achieving organizational goals, and ensuring that their achievement is carried out in accordance with the standards in the objective plan of the organization, as defined by (Hassan, 2016: 24) as: "A process by which the extent to which the goals are achieved is checked and the obstacles that impede their achievement are revealed and work on Overcoming these obstacles in the shortest possible time. While (Mala, et al, 2017: 136) defined it as: "Measuring practical results and comparing them with the objectives of the plans, and diagnosing the causes of poor performance or quality and identifying them to facilitate correction, modification or development in a way that ensures the disappearance of weakness and improve the quality and proficiency of the work performed." In light of the foregoing, it is clear that administrative control has a relationship with two important Domains of work in any institution, namely evaluation and follow-up, and monitoring of achievement and performance, and in order of the above, researchers define administrative control procedurally as: the process by which standards are compared with actual performance, and deviations are detected Find out their causes, and take the necessary actions for a correction in the hospital.

\section{Importance Of Administrative Control}

The importance of administrative control lies in the following points (Abu Hashem, 2014: 12):

A. Providing the appropriate climate in the work environment, in a way that enables the decision maker to take his decisions and better exercise his powers and administrative tasks.

B. Prevent or reduce the occurrence of errors, especially those large and costly errors.

C. Ensure that the work is going well and as planned in advance.

D. Encouraging administrative success, especially when management rewards hard-working people.

E. Preventing the occurrence of economic disasters, especially at the state level and at the level of large productive institutions and organizations, which, if such organizations go bankrupt, will lead to dire effects on the macroeconomic level.

F. Achieving development and development by assisting in the implementation of established plans and reducing waste and excess costs, disguised unemployment, and other important matters.

G. This is in addition to its traditional role in preventing the occurrence of cases of fraud, theft and corruption, and detecting and determining responsibility for them if they occur. Thus, the control process is directly and closely related to all aspects of other administrative processes.
The importance of oversight and the need for it increases with the large size of institutions and the multiplicity of their activities and programs.

\section{Dimensions Of Administrative Control}

The dimensions of administrative control adopted by the study lie in the following dimensions:

Organizational Structure: The organizational structure can be defined as "the way in which tasks are organized, the main roles of workers are identified, the information exchange system is defined, coordination mechanisms are identified, and the interaction patterns necessary between the different departments and their workers" (Al-Qaryouti, 2010: 50). In order to achieve the effectiveness of administrative control, the administrative organization structure in the institution must be characterized by the following:

That this structure represents the organizational plans to achieve the objectives of the institution.

The necessity of coherence and coordination between the main and sub-objectives.

Clarity of lines of authority and responsibility.

Flexibility and simplicity of laid plans with relative stability.

Performance Appraisal: Oversight of performance appraisal has an important role in achieving fairness and credibility in the appraisal process, and preventing bias that may occur in the appraisal process, and cause many problems, the most important of which are: the loss of workers' confidence in the results of the appraisal process, which generates a feeling of injustice, fear and threat from work in This institution, and this indicates negatively the level of services provided (Singh, 2011 303-305).

Control Tools and Means: The management of the institution uses a number of tools and means of control, and these tools and means differ according to the size, circumstances and needs of the institution. In addition to their compatibility with previously established standards, the most important of these tools are personal observation, planning budgets, reports and records, statistical data and charts, as well as control charts.

Requirements To Achieve The Effectiveness Of Administrative Control: In order to activate the role of administrative control within institutions, it is necessary to identify the requirements that help in this and work to remove all obstacles that prevent the completion of administrative control, and among the most important requirements for achieving the effectiveness of administrative control: organizational requirements, human requirements, and Materialism (Bakr, 2020: 395-397).

From the foregoing, we conclude that administrative control has a significant impact on knowing the reasons for the employees' failure in their performance. The reason may be in the administrative control systems in the hospital or in one of them, or in the skills of employees and their needs for training and knowledge of other reasons, if any, where control is a means to improve the performance of employees, not to catch their mistakes and spread fear among them.

Second: The Quality of Health Services: The interest in service institutions has increased as they are facing many challenges, as a result of the changes and developments that have taken place throughout history, and in light of these challenges, the institution should follow modern methods to confront ambiguous and complex circumstances, based on the importance of quality to achieve institutional excellence in service quality to ensure survival and continuity In light of the successive environmental changes. 


\section{The Concept of Quality of Health Services}

Through the researchers' review of a number of writings and research that dealt with the study of the quality of health services, some attempts to define it can be presented. The quality of health services was defined as: And (Abu Al-Nasr, 2008: 35) defined it as "guaranteeing and improving the level of health care, Providing services, units, and hospitals to maximize personal and clinical capacity and raise the level of medical and nursing education and in-service training. While (Bashiwa and Al-Barawi, 2011: 93) defined it as "a method for studying and continuously improving the processes of providing health and clinical care services to meet the needs of patients and others, and it is the degree to which health services provided to individuals and groups increase the desired outcome within a certain economic framework, and balance risk-benefit in line with modern requirements for practicing the profession. He referred to it (Atta, 2011: 310) as: "Meeting the needs and desires of patients, commitment to everything related to patients' affairs through continuous research and choosing the best ways and means to meet their needs. The quality of health services is defined by the administration by satisfying the needs of the consumer", while (Dora et all., 2018: 359) defined the quality of health services as "the extent to which the health organization's workers care about patients and meet the humanitarian needs of them, which the patient perceives in reality." And he defined it (Javed, et al, 2019: 170) as "the patients' judgment or their impression of the general excellence and superiority of the health service provided." The researchers (Al-Saadi and AlRubaie, 2021: 168) referred to it as "the patients' judgment and their impression of the health services provided to them, and the contrast between those services and their expectations for them, in a way that ensures the provision of these services in a timely manner and reduces the waiting time for the customer and satisfaction with them." In order of the above, researchers define the procedural quality of health services as: the degree of hospital compliance with medical quality standards when providing high-quality health care services to patients and beneficiaries with the aim of achieving the desired results of achieving patient and beneficiary's satisfaction.

\section{The Importance of The Quality of Health Services}

(Al-Dulaimi, 2005: 32) believes that the importance of the quality of health services lies in the following points:

A. Helps the growth and stability of the hospital.

B. It works on the needs and desires of the patient.

C. Participate in raising the efficiency of the hospital.

D. It helps reduce the cost of producing health services through the optimal use of resources.

E. The hospital cooperates to gain a comparative advantage over competing hospitals.

F. The researchers believe that the quality of health services is fundamental and important to the success of the hospital in providing distinguished health services to patients, as it helps to attract many patients to receive the health service in the hospital, and makes the hospital enjoy a competitive advantage compared to its competitors, as well as maximizing patient retention, and raising the level of health service provision for patients.

\section{Dimensions Of the Quality of Health Services}

Many studies dealt with the dimensions of service quality in general, including health dimensions. Cotler focused on the five dimensions, where he confirmed the existence of five dimensions of service quality in general. The dimensions and components of health service quality are as follows (Abdelkader,
2015: 904):

A. Tangible Aspects: It refers to the appearance of the physical facilities available to the service organization, the equipment, the appearance of individuals and those dealing with service providers, tools and means of communication with them. etc.).

B. Reliability: It refers to the ability of the service-providing organization to perform the promised service in a reliable manner, and also with a high degree of validity and accuracy.

C. Response: It relates to the ability, desire and willingness of service providers to be permanently at the service of customers and their ability to perform the service for them when they need it. It refers to the initiative to help customers and respond quickly to their inquiries, the ability, desire and willingness of service providers to be permanently at the service of customers, and their ability to perform service for them when they need it (AI-Tai, 2009: 55).

D. Empathy: It refers to the extent to which the service provider is able to identify and understand the needs of customers and provide them with care and attention. In hospitals, it means the degree of personal attention and care towards the patient.

E. Safety: It refers to individuals' attitudes and behavior, and individuals' ability to provide services in a friendly, kind and competent manner (Pakurar, et al, 2019: 5), and it also refers to the qualities that employees have of knowledge and ability to provide the service.

It is clear from the foregoing that the issue of administrative control and its impact on improving the quality of health service has received increasing attention in most institutions, especially after institutions in general and hospitals in particular paid attention to the importance of quality and the extent of its contribution to improving performance, and looking at quality as a competitive weapon with which institutions face internal and external challenges.

\section{Methodology and Procedures}

First: The Study Approach: The study followed the descriptive analytical approach, which depends on the study of reality or the apparent, and is concerned with describing it accurately and expressing it descriptively or quantitatively through the use of the applied method, by collecting data, analyzing its contents and testing the study hypotheses.

Second: The Study Population and Sample: The study population is defined as all the vocabulary of the phenomenon that the researchers study, and based on the study problem and its objectives, the target community consists of all nursing workers mainly in Al-Awda Hospital, in addition to (anesthesia technicians, radiology, physical therapy, laboratories, and pharmacists). ) This is due to the similarity of the nature of work with the nurses, who number approximately (60) male and female employees, where the administrative employees and workers in maintenance and services were excluded due to the nature of the study (Statistics of the Personnel Department, 202).

The researchers used the comprehensive "survey" survey method for all members of the study population; Due to the small size of the study population, all questionnaires were retrieved, and after examination, it was found that all questionnaires are valid for analysis. 


\begin{tabular}{|l|l|l|l|}
\hline \multicolumn{2}{|l|}{ Personal Data } & The Number & Percentage \% \\
\hline \multirow{2}{*}{ Gender } & Male & 38 & 63.3 \\
\cline { 2 - 4 } & Female & 22 & 36.7 \\
\hline \multirow{3}{*}{ Scientific Qualification } & Diploma Degree & 12 & 20.0 \\
\cline { 2 - 4 } & Bachelor Degree & 34 & 56.7 \\
\cline { 2 - 4 } & Postgraduate Degree & 14 & 23.3 \\
\hline \multirow{3}{*}{ Years Of Service } & 5 years or less & 14 & 23.3 \\
\cline { 2 - 4 } & From 5- Less than 10 years old & 27 & 45.5 \\
\cline { 2 - 4 } & 10 years and over & 19 & 31.7 \\
\hline
\end{tabular}

Table 1: Distribution of study sample members according to personal data (from $=60$ )

Through table (1) it is clear that:

The percentage of $(63.3 \%)$ of the study sample are males, while $(36.7 \%)$ are females. The researchers refer the result to the fact that these numbers are relatively consistent with the difference in the ratio of the numbers of male and female employees in the Palestinian public and private sectors, given that they are consistent with the reports issued by the Palestinian Central Bureau of Statistics for the year (2017) on the labor force survey in Palestine, where the report indicated that the percentage of women female workers in Palestine (19.4\%), while the percentage of males is $(81.6 \%$ ) (The Palestinian Central Bureau of Statistics, 4/24/2021).

$(20.0 \%)$ of the study sample have a diploma, $(56.7 \%)$ have a bachelor's degree, while $(23.3 \%)$ have a postgraduate qualification. This indicates that the researched category is a scientifically qualified category, and this reflects the extent of AlAwda Hospital's interest in employing highly qualified staff, because working in the hospital requires academic qualifications not less than a bachelor's to enable it to complete work efficiently, and the possibility of pursuing scientific and professional development in the Domain of specialization .

$(23.3 \%)$ of the study sample had years of service less than 5 years, $(45.5 \%)$ years of service ranged from 5 to less than 10 years, and (31.7\%) years of service were more than 10 years. This means diversity in the experiences of the administrative staff in Al-Awda Hospital, and that most of the respondents have appropriate years of service in their Domain of work, and they can be able to express their opinions about the impact of administrative control on improving the quality of health services.

Third: The Study Tool: The researchers developed a questionnaire based on theoretical literature and previous studies in order to study "the effect of administrative control on improving the quality of health services: an applied study in AlAwda Hospital in North Gaza Governorate", where the questionnaire consisted of three main Domains:

The First Section: It is the personal data of the respondents (gender, educational qualification, years of service).

Section Two: It is about administrative control, divided into (4) Domains, and it consists of (20) paragraphs as follows:

The First Domain: the organizational structure, and it consists of (5) paragraphs.

The Second Domain: performance evaluation, and it consists of (5) paragraphs.

The Third Domain: Control tools and means, and it consists of (5) paragraphs.

The Fourth Domain: the requirements for achieving the effectiveness of administrative control, and it consists of (5) paragraphs.

Section Three: It is about the quality of health service, divided into (5) Domains, and it consists of (25) paragraphs as follows:

The First Domain: tangibility, and it consists of (5) paragraphs.

The Second Domain: reliability, and it consists of (5) paragraphs.

The Third Domain: the response, and it consists of (5) paragraphs.

The Fourth Domain: empathy, and it consists of (5) paragraphs.

The Fourth Domain: empathy, and it consists of (5) paragraphs.

The answers to all the paragraphs were according to the fivepoint Likert Scale, as shown in Table (2):

\begin{tabular}{|c|c|c|c|c|}
\hline Response & Strongly Agree & Agree & Neutral & Disagree \\
\hline Degree & 5 & 4 & 3 & 2 \\
\hline
\end{tabular}

Table 2: The scores of the five-point Likert scale to measure the responses of the respondents

Fourth: The Validity of The Questionnaire: What is meant by the validity of the questionnaire is the questionnaire's measurement of what it was designed to measure, so that the questionnaire is comprehensive of all the elements that must be included in the analysis, in addition to the clarity of the paragraphs, so that they are understandable to everyone who uses it (Al-Jerjawi, 2010: 105). The validity of the questionnaire was ascertained through: the apparent validity "the sincerity of the opinions of the arbitrators", and the internal consistency, where the values of the correlation coefficient ranged between (0.350-0.746), which are strong correlation coefficients and indicate the strength of the correlation of the paragraphs with the domains to which they belong, and thus the paragraphs are considered true for what was developed To measure it, the validity of the questionnaire was also confirmed through structural validity, as the results of all correlation coefficients in all Domains of the questionnaire showed that it was statistically significant at a significant level $(\alpha \geq 0.05)$, where the value of the
Pearson correlation coefficient for the dimensions of administrative control was (0.900), and for the dimensions of service quality. Health (0.788), and thus all Domains of the questionnaire are considered valid for what they were designed to measure.

Fifth: The Stability of the Resolution: What is meant by the stability of the resolution is "that the questionnaire gives the same results if it is re-applied several times in a row" (Al-Jerjawi, 2010: 97). Adjustment (0.719), in addition to Cronbach's alpha coefficient, where it was found that its value for the resolution as a whole is $(0.707)$, and these values are considered high and reassuring for the stability of the study tool.

It can be concluded from the results of the validity and reliability tests that the questionnaire is honest in measuring what it was designed to measure, and is very stable, which qualifies it to be an appropriate and effective measurement tool for this study and can be applied with confidence.

Sixth: Normal Distribution Test: The Kolmogorov-Smirnov 
Test was used to test whether the data follow a normal distribution or not, as it was found that the test value is $(0.443)$ and the probabilistic value (Sig.) is (0.990), which is It is greater than the significance level (0.05), so the data distribution follows a normal distribution, where parametric tests were used to analyze the data and test the study hypotheses.

Seventh: The Statistical Tools Used: The data was unloaded and analyzed through the Statistical Package for the Social Sciences (SPSS22), where the following statistical tests were used:

1. Percentages and frequencies: to describe the study sample.

2. Arithmetic mean, relative weight, and standard deviation.

3. Cronbach's Alpha test to determine the stability of the resolution items.

4. The Kolmogorov-Smirnov Test to test whether the data follow a normal distribution.
5. T-test in the case of one sample (T-Test), and the researchers used it to verify the significance of the average for each of the questionnaire items.

6. Pearson Correlation Coefficient: This test is based on studying the relationship between two variables. The researchers used it to calculate the internal consistency and the structural validity of the questionnaire, as well as to study the relationship between the domains.

7. Multiple Linear Regression- Model.

Eighth: Analysis and Discussion of the Study Results

The results of the study will be presented and discussed as follows:

Answer To the First Question

Q1-: What is the reality of administrative control in Al-Awda Hospital in North Gaza Governorate?

The arithmetic mean, relative, and standard deviation were used to determine the degree of agreement, as in the following table:

\begin{tabular}{|c|c|c|c|c|c|c|}
\hline \# & Statement & SMA & $\begin{array}{l}\text { Relative } \\
\text { Weight }\end{array}$ & $\begin{array}{l}\text { Standard } \\
\text { Deviation }\end{array}$ & Sig. & Rank \\
\hline \multicolumn{7}{|c|}{ First Domain: Organizational Structure } \\
\hline & $\begin{array}{l}\text { The hospital's organizational structure is accurate and } \\
\text { clear. }\end{array}$ & 4.12 & 82.4 & 0.761 & *0.000 & 4 \\
\hline & $\begin{array}{l}\text { The hospital's organizational structure achieves its } \\
\text { objectives. }\end{array}$ & 4.00 & 80.0 & 0.759 & *0.000 & 5 \\
\hline & $\begin{array}{l}\text { The organizational structure facilitates communication } \\
\text { and communication between employees. }\end{array}$ & 4.67 & 93.4 & 0.510 & *0.000 & 1 \\
\hline & $\begin{array}{l}\text { The organizational structure of the hospital clarifies the } \\
\text { powers and responsibilities among the employees. }\end{array}$ & 4.52 & 90.4 & 0.725 & *0.000 & 2 \\
\hline & $\begin{array}{l}\text { The organizational structure facilitates supervision of the } \\
\text { subordinates. }\end{array}$ & 4.30 & 86.0 & 0.696 & *0.000 & 3 \\
\hline \multicolumn{2}{|r|}{ All paragraphs of the Domain together } & 4.32 & 86.40 & 0.412 & ${ }^{\star} 0.000$ & \\
\hline \multicolumn{7}{|c|}{ The Second Domain: Performance Appraisal } \\
\hline & $\begin{array}{l}\text { Regulatory standards are defined to monitor performance } \\
\text { in the hospital. }\end{array}$ & 4.20 & 84.00 & 0.708 & *0.000 & 5 \\
\hline & Clear performance standards for all employees. & 4.53 & 90.60 & 0.676 & ${ }^{\star} 0.000$ & 1 \\
\hline & Modify hospital performance standards if necessary. & 4.28 & 85.60 & 0.691 & ${ }^{*} 0.000$ & 4 \\
\hline & The performance evaluation criteria are objective. & 4.45 & 89.00 & 0.649 & ${ }^{*} 0.000$ & 2 \\
\hline & $\begin{array}{l}\text { The performance appraisal process contributes to } \\
\text { addressing deficiencies. }\end{array}$ & 4.33 & 86.60 & 0.729 & *0.000 & 3 \\
\hline \multicolumn{2}{|r|}{ All paragraphs of the Domain together } & 4.36 & 87.20 & 0.416 & ${ }^{\star} 0.000$ & \\
\hline \multicolumn{7}{|c|}{ The Third Domain: Tools And Means Of Control } \\
\hline & $\begin{array}{l}\text { Oversight is exercised in the hospital through monthly } \\
\text { reports. }\end{array}$ & 4.00 & 80.00 & 0.864 & *0.000 & 1 \\
\hline & $\begin{array}{l}\text { Administrative control is exercised through unannounced } \\
\text { visits to hospital departments. }\end{array}$ & 3.83 & 76.60 & 0.924 & *0.000 & 3 \\
\hline & $\begin{array}{l}\text { Administrative control is exercised through periodic } \\
\text { meetings and meetings. }\end{array}$ & 3.78 & 75.60 & 0.940 & *0.000 & 4 \\
\hline & $\begin{array}{l}\text { Administrative control is exercised through the review of } \\
\text { records. }\end{array}$ & 3.58 & 71.60 & 0.962 & *0.000 & 5 \\
\hline & $\begin{array}{l}\text { Administrative control is exercised through patient } \\
\text { complaints. }\end{array}$ & 3.83 & 76.60 & 0.785 & *0.000 & 2 \\
\hline \multicolumn{2}{|r|}{ All paragraphs of the Domain together } & 3.80 & 76.00 & 0.462 & ${ }^{*} 0.000$ & \\
\hline \multicolumn{7}{|c|}{ Fourth Domain: Requirements To Achieve The Effectiveness Of Administrative Control } \\
\hline & $\begin{array}{l}\text { The hospital management believes in the importance of } \\
\text { having an effective control system. }\end{array}$ & 3.60 & 72.00 & 0.785 & *0.000 & 5 \\
\hline & $\begin{array}{l}\text { Control provides the necessary information at the right } \\
\text { time for decision-making. }\end{array}$ & 4.25 & 85.00 & 0.836 & *0.000 & 4 \\
\hline & The control system provides accurate and clear results. & 4.47 & 89.40 & 0.724 & ${ }^{*} 0.000$ & 1 \\
\hline & $\begin{array}{l}\text { Facilitates communication between the supervisory } \\
\text { authorities and the administrative levels of the hospital. }\end{array}$ & 4.45 & 89.00 & 0.675 & *0.000 & 2 \\
\hline & The regulatory procedures are flexible. & 4.42 & 88.40 & 0.720 & ${ }^{*} 0.000$ & 3 \\
\hline \multicolumn{2}{|r|}{ All paragraphs of the Domain together } & 4.23 & 84.60 & 0.485 & ${ }^{*} 0.000$ & \\
\hline \multicolumn{2}{|r|}{ The Total Degree Of The Administrative Control Domains } & 4.18 & 83.60 & 0.274 & ${ }^{\star} 0.000$ & \\
\hline
\end{tabular}

Table 3: Arithmetic mean, relative, and standard deviation for all Domains of administrative control 
* The arithmetic mean is statistically significant at the 0.05 level of significance.

It is clear from the previous table (3) that:

1. That the arithmetic mean of the first Domain "Organizational Structure" equals (4.32) that is, the relative arithmetic mean $(86.40 \%)$, the standard deviation value (0.412) and that the probabilistic value (Sig) equals (0.000) and this means that there is a very large approval by the sample members On the paragraphs of this Domain, the researchers attribute the result to the fact that the organizational structure of the hospital was designed appropriately by experts in cooperation with the hospital administration so that it facilitates the process of communication and communication between workers, and clarifies the authorities and responsibilities of hospital workers, and facilitates the process of supervision and control over subordinates, and facilitates the exchange of communications Formal and informal between employees in a way that contributes to achieving the hospital's goals.

2. The arithmetic mean of the second Domain "performance evaluation" is equal to (4.36), meaning that the relative arithmetic mean $(87.20 \%)$, the value of the standard deviation (0.416) and that the probability value (Sig) equals (0.000) and this means that there is a very large degree of approval by individuals The sample is based on the paragraphs of this Domain, and the researchers attribute the result to the fact that the administration of AlAwda Hospital used experts in designing the performance evaluation criteria in the hospital, as the administration was keen that the evaluation criteria be appropriate and clear for all employees, because the supervisory standards contribute to achieving transparency and integrity in judging the performance of employees. Also, the control standards help in detecting deviations and errors in the performance of employees, in order to work on them by the hospital management in a timely manner.

3. The arithmetic mean of the third Domain "controlling tools and means" is equal to (3.80), meaning that the relative arithmetic mean $(76.00 \%)$, the standard deviation value (0.462) and that the probabilistic value (Sig) equals $(0.000)$ and this means that there is a large degree of approval by individuals The sample is based on the paragraphs of this Domain, and the researchers attribute the result to the fact that the administration of Al-Awda Hospital exercises administrative control through monthly reports and periodically reviewing records, in addition to reviewing complaints submitted by patients and beneficiaries to work on them, and conducting meetings and periodic meetings with workers to listen to obstacles and problems facing them to work out appropriate solutions to address them.

4. The arithmetic mean of the fourth Domain "requirements to achieve the effectiveness of administrative control" is equal to (4.23) that is, the relative arithmetic mean $(84.60 \%)$, the value of the standard deviation is $(0.485)$ and that the probabilistic value ( $\mathrm{Sig})$ is equal to $(0.000)$ and this means that there is agreement to a very large degree The researchers attributed this to the effectiveness of the control system in Al-Awda Hospital, which is characterized by flexibility, and the control system provides accurate and clear results on the workflow, provides the necessary information in a timely manner for decision-making, and facilitates communication between the supervisory authorities and the hospital's administrative levels.

In general, it can be said that the arithmetic mean is (4.18), the relative arithmetic mean is $(83.60 \%)$, the standard deviation is (0.274), and that the probability value (Sig) is $(0.000)$ and this means that there is a large degree of approval by the sample members On the paragraphs of administrative control in general, and researchers attribute this to the importance of administrative control in all its dimensions, as it is an important way to identify the efforts of workers, and that what is accomplished is in accordance with established plans, and programs prepared within the systems, regulations, and instructions regulating performance, in addition to identifying human and material resources. waste in the hospital, and work to solve the problems facing the hospital to improve the quality of health services provided to patients. This result agreed with the findings of the study (Mohamed, 2019), and the study (Sedky and Hamoudi, 2017), and the result differed with the findings of the study (Al-Saadi and Al-Rubaie, 2021), and the study (Dora et all, 2018).

\section{Answer To the Second Question}

Q2-: What is the level of quality of health services in Al-Awda Hospital in North Gaza Governorate?

The arithmetic mean, relative, and standard deviation were used to determine the degree of agreement, as in the following table:

\begin{tabular}{|c|c|c|c|c|c|c|}
\hline \# & Statement & SMA & $\begin{array}{l}\text { Relative } \\
\text { Weight }\end{array}$ & $\begin{array}{l}\text { Standard } \\
\text { Deviation }\end{array}$ & Sig. & Rank \\
\hline \multicolumn{7}{|c|}{ The First Domain: Tangibility } \\
\hline & The hospital staff always looks decent. & 4.55 & 91.0 & 0.622 & ${ }^{*} 0.000$ & 3 \\
\hline & $\begin{array}{l}\text { The hospital has advanced medical and technical } \\
\text { equipment and devices. }\end{array}$ & 4.55 & 91.0 & 0.699 & ${ }^{*} 0.000$ & 4 \\
\hline & $\begin{array}{l}\text { There is a high level of hygiene in the hospital } \\
\text { premises. }\end{array}$ & 4.65 & 93.0 & 0.577 & ${ }^{*} 0.000$ & 1 \\
\hline & $\begin{array}{l}\text { The appearance of the hospital is compatible with the } \\
\text { nature of the services provided. }\end{array}$ & 4.60 & 92.0 & 0.588 & ${ }^{*} 0.000$ & 2 \\
\hline & $\begin{array}{l}\text { The hospital has comfortable and adequate public } \\
\text { facilities. }\end{array}$ & 3.27 & 65.4 & 0.936 & ${ }^{\star} 0.000$ & 5 \\
\hline & Jaragraphs of the Domain together & 4.32 & 86.4 & 0.389 & ${ }^{*} 0.000$ & \\
\hline \multicolumn{7}{|c|}{ The Second Domain: Reliability } \\
\hline & $\begin{array}{l}\text { The hospital provides medical service at the specified } \\
\text { times. }\end{array}$ & 4.55 & 91.00 & 0.565 & ${ }^{*} 0.000$ & 1 \\
\hline & $\begin{array}{l}\text { The hospital has been providing medical services } \\
\text { properly from the very beginning. }\end{array}$ & 4.40 & 88.00 & 0.643 & ${ }^{*} 0.000$ & 2 \\
\hline & $\begin{array}{l}\text { The service is provided in the hospital at the times } \\
\text { promised. }\end{array}$ & 4.15 & 83.00 & 0.732 & ${ }^{*} 0.000$ & 3 \\
\hline
\end{tabular}




\section{GENERAL MANAGEMENT}

\begin{tabular}{|c|c|c|c|c|c|c|}
\hline \# & Statement & SMA & $\begin{array}{l}\text { Relative } \\
\text { Weight }\end{array}$ & $\begin{array}{l}\text { Standard } \\
\text { Deviation }\end{array}$ & Sig. & Rank \\
\hline & $\begin{array}{l}\text { There is a special attention on the part of the } \\
\text { administration to the problems of patients. }\end{array}$ & 4.07 & 81.40 & 0.686 & ${ }^{*} 0.000$ & 4 \\
\hline & $\begin{array}{l}\text { Hospital management deals with patient records with } \\
\text { honesty and trust. }\end{array}$ & 3.687 & 73.74 & 0.873 & ${ }^{*} 0.000$ & 5 \\
\hline & Jaragraphs of the Domain together & 4.17 & 83.40 & 0.378 & ${ }^{*} 0.000$ & \\
\hline \multicolumn{7}{|c|}{ The Third Domain: Response } \\
\hline & $\begin{array}{l}\text { The hospital informs patients of when the service will } \\
\text { be provided to them. }\end{array}$ & 4.05 & 81.00 & 0.811 & ${ }^{*} 0.000$ & 3 \\
\hline & $\begin{array}{l}\text { The hospital provides service to patients quickly and } \\
\text { without delay. }\end{array}$ & 4.48 & 89.60 & 0.701 & ${ }^{*} 0.000$ & 1 \\
\hline & Hospital staff want to help patients. & 4.25 & 85.00 & 0.773 & ${ }^{*} 0.000$ & 2 \\
\hline & $\begin{array}{l}\text { The hospital administration responds immediately to } \\
\text { patients' complaints. }\end{array}$ & 3.37 & 67.40 & 0.991 & $* 0.000$ & 5 \\
\hline & $\begin{array}{l}\text { The hospital provides medical service to patients } \\
\text { around the clock. }\end{array}$ & 3.48 & 69.60 & 0.892 & ${ }^{*} 0.000$ & 4 \\
\hline & Jaragraphs of the Domain together & 3.92 & 78.40 & 0.393 & ${ }^{*} 0.000$ & \\
\hline \multicolumn{7}{|c|}{ Fourth Domain: Empathy } \\
\hline & $\begin{array}{l}\text { The working hours in the hospital are suitable for all } \\
\text { patients. }\end{array}$ & 4.17 & 83.40 & .763 & *0.000 & 3 \\
\hline & Hospital staff maintain good relations with patients. & 4.33 & 86.60 & .705 & ${ }^{\star} 0.000$ & 1 \\
\hline & The hospital staff appreciates the patient's conditions. & 4.05 & 81.00 & .622 & ${ }^{*} 0.000$ & 4 \\
\hline & $\begin{array}{l}\text { The patient's welfare and health are a priority of the } \\
\text { hospital management. }\end{array}$ & 4.17 & 83.40 & .717 & *0.000 & 2 \\
\hline & Hospital staff understand patients' personal needs. & 3.53 & 70.60 & 1.06 & ${ }^{*} 0.000$ & 5 \\
\hline & Jaragraphs of the Domain together & 4.05 & 81.00 & 0.365 & ${ }^{*} 0.000$ & \\
\hline \multicolumn{7}{|c|}{ Fifth Domain: Safety } \\
\hline & The patient feels safe in the hospital. & 3.75 & 75.00 & 0.895 & ${ }^{\star} 0.000$ & 5 \\
\hline & $\begin{array}{l}\text { Staff behavior enhances patient confidence in the } \\
\text { hospital. }\end{array}$ & 3.57 & 71.40 & 0.981 & ${ }^{*} 0.000$ & 4 \\
\hline & Hospital staff treat patients appropriately. & 3.60 & 72.00 & 0.906 & ${ }^{\star} 0.000$ & 1 \\
\hline & $\begin{array}{l}\text { The hospital provides adequate information to the } \\
\text { patient about his health condition. }\end{array}$ & 3.55 & 71.00 & 0.910 & *0.000 & 2 \\
\hline & $\begin{array}{l}\text { The prices of hospital services are appropriate and } \\
\text { within the capacity of the patient. }\end{array}$ & 3.53 & 70.60 & 0.791 & ${ }^{*} 0.000$ & 3 \\
\hline & Jaragraphs of the Domain together & 3.60 & 72.00 & 0.510 & ${ }^{\star} 0.000$ & \\
\hline & $\begin{array}{l}\text { Overall Degree Of The Quality Of Health Services } \\
\text { nains }\end{array}$ & 4.01 & 80.20 & 0.213 & $* 0.000$ & \\
\hline
\end{tabular}

Table 4: the arithmetic mean, relative, and standard deviation of all items of quality of health services

* The arithmetic mean is statistically significant at the 0.05 It is clear from the previous table (4) that:

1. The arithmetic mean of the first Domain "concrete" is equal to (4.32), meaning that the relative arithmetic mean $(86.40 \%)$, the value of the standard deviation is $(0.389)$ and that the probability value ( $\mathrm{Sig})$ is equal to (0.000), and this means that there is a very great agreement by the sample members on The paragraphs of this Domain, and the researchers attribute this to the importance of hygiene in Al-Awda Hospital, as it helps prevent the spread of microbes, germs and diseases in the hospital departments, and the appearance of the hospital is compatible with the nature of health services provided to patients, in addition to that, hospital workers have a decent appearance that reflects positively on patients The hospital is also equipped with advanced medical equipment and devices that suit the nature of work.

2. The arithmetic mean of the second Domain "reliability" is equal to (4.36), meaning that the relative arithmetic mean $(87.20 \%)$, the value of the standard deviation $(0.416)$ and that the probability value (Sig) is equal to $(0.000)$, which means that there is a very large approval by the sample members On the paragraphs of this Domain, the researchers attribute the result to the fact that the level of significance.

administration of Al-Awda Hospital seeks to provide its medical services on the specified dates with a high degree of accuracy, and takes into account patients' satisfaction with the quality of its services, as there is a special interest on the part of the hospital administration to solve the problems facing patients, and deals with records Patients honestly and confidently.

3. The arithmetic mean of the third Domain "response" is equal to (3.92), that is, the relative arithmetic mean $(78.40 \%)$, the standard deviation value is $(0.393)$ and the probabilistic value (Sig) is equal to $(0.000)$, which means that there is a large approval by the sample members on Paragraphs of this Domain, and the researchers attribute the result to the fact that the administration of Al-Awda Hospital is always ready to provide health services to patients with high quality and efficiency, and Al-Awda Hospital is ready to provide health service to patients on a permanent and continuous basis, and at the time patients need it, they are always ready to serve The patients.

4. The arithmetic mean of the fourth Domain "sympathy" is equal to (4.05), meaning that the relative arithmetic mean $(81.00 \%)$, the standard deviation value $(0.365)$ and the 
probabilistic value (Sig) equals (0.000) and this means that there is a large approval by the sample members on Paragraphs of this Domain, and the researchers attribute the result to the ability of the Al-Awda Hospital administration to understand and determine the needs of patients, and to provide patients with care and attention. The basis of emotional interaction in the hospital is linked to establishing good relations between hospital workers with patients, and considering the patient's interest and health among the priorities of the hospital management, and appropriate times Work in the hospital with all patients.

5. The arithmetic mean of the fifth Domain "safety" is equal to (3.60), meaning that the relative arithmetic mean $(72.00 \%)$, the value of the standard deviation (0.510) and that the probability value (Sig) is equal to (0.000), which means that there is a large agreement by the sample members on The paragraphs of this Domain, and the researchers attribute the result to the feeling of trust and safety by the administration of Al-Awda Hospital about the health services that are provided to patients, in addition to the patient's feeling of safety in Al-Awda Hospital in terms of the hospital staff treating patients properly, and providing them with sufficient information about their health status in a way that enhances of patients' confidence in the hospital.

In general, it can be said that the arithmetic mean equals (4.01), that the relative arithmetic mean equals (80.20\%), the value of the standard deviation is $(0.213)$, and that the probability value (Sig) equals $(0.000)$ and this means that there is a large approval by the sample members On the paragraphs of administrative control in general, the researchers attribute this to the interest of the Al-Awda Hospital administration in the quality of health services provided to patients, as the hospital administration considers the quality of health services one of the most important and vital factors for the hospital, as it helps it achieve success and stability and enhance its competitive advantage and superiority in the long run. The more attention is paid to training hospital staff, which leads to an increase in their knowledge, which will reflect positively on improving the quality of health services provided. This result agreed with the findings of a study (Abu Salmi and Abbas, 2016), and the result differed with the findings of a study (Omar, 2014).

\section{Ninth: Testing the Hypotheses of the Study}

Ho1: There is a statistically significant relationship at the level of significance $(\alpha \leq 0.05)$ between the dimensions of administrative control (organizational structure, performance evaluation, control tools and means, requirements to achieve the effectiveness of administrative control) and improving the quality of health services in Al-Awda Hospital.

To test this hypothesis, the "Pearson correlation coefficient" test was used, and the following table illustrates this.

\begin{tabular}{|c|c|c|}
\hline Hypotheses & $\begin{array}{c}\text { Pearson Correlation } \\
\text { Coefficient }\end{array}$ & Sig. \\
\hline $\begin{array}{l}\text { There is a statistically significant relationship at the level of significance }(\alpha \leq 0.05) \text { between } \\
\text { the dimensions of administrative control (organizational structure, performance evaluation, } \\
\text { control tools and means, requirements to achieve the effectiveness of administrative } \\
\text { control) and improving the quality of health services in Al-Awda Hospital. }\end{array}$ & 0.509 & ${ }^{*} 0.000$ \\
\hline $\begin{array}{l}\text { There is a statistically significant relationship at a significant level }(\alpha \leq 0.05) \text { between the } \\
\text { dimension of the organizational structure as one of the dimensions of administrative } \\
\text { control and improving the quality of health services in Al-Awda Hospital. }\end{array}$ & 0.340 & ${ }^{*} 0.008$ \\
\hline $\begin{array}{l}\text { There is a statistically significant relationship at a significant level }(\alpha \leq 0.05) \text { between the } \\
\text { performance evaluation dimension as one of the dimensions of administrative control and } \\
\text { improving the quality of health services in Al-Awda Hospital. }\end{array}$ & 0.402 & ${ }^{*} 0.001$ \\
\hline $\begin{array}{l}\text { There is a statistically significant relationship at a significant level }(\alpha \leq 0.05) \text { between the } \\
\text { tools and controls dimension as one of the dimensions of administrative control and } \\
\text { improving the quality of health services in Al-Awda Hospital. }\end{array}$ & 0.256 & ${ }^{* *} 0.048$ \\
\hline $\begin{array}{l}\text { There is a statistically significant relationship at a significant level }(\alpha \leq 0.05) \text { between the } \\
\text { dimension of requirements to achieve the effectiveness of administrative control as one of } \\
\text { the dimensions of administrative control and improving the quality of health services in Al- } \\
\text { Awda Hospital. }\end{array}$ & 0.273 & ${ }^{* *} 0.035$ \\
\hline
\end{tabular}

* The correlation is statistically significant at $(\alpha \leq 0.05)$ significance level.

Table 5: Correlation coefficient between administrative control and improving the quality of health services

Table (5) shows that the correlation coefficient is equal to (0.509), and that the probabilistic value (Sig.) is $\left(0.000^{*}\right)$ which is less than the significance level (0.05), and this indicates the existence of a direct statistically significant relationship between management oversight and the quality of improving health services At Al-Awda Hospital. When studying the dimensions of the reality of work stress, the following was found: 
1. There is a statistically significant relationship between the dimension of the organizational structure as one of the dimensions of administrative control and improving the quality of health services in Al-Awda Hospital. The correlation coefficient was $(0.340)$ and the statistical significance was $\left(0.008^{*}\right)$, which is less than $(0.05)$.

2. There is a statistically significant relationship between the performance evaluation dimension as one of the dimensions of administrative control and improving the quality of health services in Al-Awda Hospital. The correlation coefficient was $(0.402)$ and the statistical significance was $\left(0.001^{*}\right)$, which is less than $(0.05)$.

3. There is a statistically significant relationship between the dimension of monitoring tools and means as one of the dimensions of administrative control and improving the quality of health services in Al-Awda Hospital. The correlation coefficient was (0.256) and the statistical significance was $\left(0.048^{* *}\right)$, which is less than $(0.05)$.

4. There is a statistically significant relationship between the dimension of requirements for achieving the effectiveness of administrative control as one of the dimensions of administrative control and improving the quality of health services in Al-Awda Hospital. The correlation coefficient was $(0.273)$ and the statistical significance was $\left(0.035^{\star \star}\right)$, which is less than (0.05).

The researchers attribute the result to the availability of a control system in Al-Awda Hospital that can detect deviations and work to correct them as they occur, and contribute to activating administrative control tools such as direct or periodic control, to ensure the workflow as planned, in addition to the availability of administrative control requirements in terms of prices Health services are appropriate and within the ability of patients, as well as proper treatment by hospital staff with patients. The result of the hypothesis agreed with some of the results of previous studies, such as the study (Abu Salmi and Abbas, 2016) and the study (Omar, 2014), and the results of the study did not differ with any of the results of the previous studies.

Ho2: There is a statistically significant effect at the level of significance $(\alpha \leq 0.05)$ for the dimensions of administrative control (organizational structure, performance evaluation, monitoring tools and means, requirements to achieve the effectiveness of administrative control) on improving the quality of health services in Al-Awda Hospital.

To test this hypothesis, multiple linear regression was used and the following table illustrates this:

\begin{tabular}{|l|c|c|c|}
\hline \multicolumn{1}{|c|}{ Independent Variables } & $\begin{array}{c}\text { Regression } \\
\text { Coefficients }\end{array}$ & T- Value Test & Sig. \\
\hline Fixed Amount & 0.289 & 1.376 & 0.154 \\
\hline Organizational Chart. & 0.104 & 2.098 & 0.027 \\
\hline Performance Evaluation. & 0.346 & 7.287 & 0.001 \\
\hline Control Tools And Means. & 0.167 & 3.475 & 0.000 \\
\hline $\begin{array}{l}\text { Requirements To Achieve The } \\
\text { Effectiveness Of Administrative Control. }\end{array}$ & 0.264 & 5.165 & 0.000 \\
\hline \multicolumn{2}{|c|}{ Correlation coefficient $=0.560$} & & Adjusted coefficient of determination $=0.517$ \\
\hline \multicolumn{2}{|c|}{ F- value Test $=4.752$} & \multicolumn{2}{c|}{ P value $=0.000$} \\
\hline
\end{tabular}

Table 6: Multiple Regression Analysis

From the results shown in Table (6), the following can be concluded:

- Correlation coefficient $=0.560$, and adjusted coefficient of determination $=0.517$, which means that $(51.7 \%)$ of the change in the quality of health services in Al-Awda Hospital was explained by the linear relationship and the remaining percentage may be due to other factors affecting the quality of health services in Al-Awda Hospital.

- The value of the test $\mathrm{F}$ was 4.752 , and the probability value is $(0.000)$, which means rejecting the null hypothesis and accepting the existence of a statistically significant relationship between administrative control and the quality of health services in Al-Awda Hospital.

- It was found that the variable (organizational structure, performance evaluation, monitoring tools and means, requirements to achieve the effectiveness of administrative control) affects the improvement of the quality of health services in Al-Awda Hospital.

\section{Regression Equation:}

- Job performance $=0.289+0.104$ (organizational structure) +0.348 (performance evaluation) +0.167 (control tools and means) +0.264 (requirements to achieve the effectiveness of management control).

- This may be due to the importance and necessity of having an administrative control system in Al-Awda Hospital, and its role in the success of the health services provided to patients, and one of the important matters achieved by the availability of an administrative control system in the hospital is to monitor the performance of employees and ensure their optimal use of the available resources to control the high cost of health services, in addition. To prevent errors in the provision of health services. The result of the hypothesis agreed with some of the results of previous studies, such as the study (Abu Salmi and Abbas, 2016) and the study (Omar, 2014), and the results of the study did not differ with any of the results of the previous studies. 


\section{Conclusions}

The study concluded a set of results as follows:

1. The results of the study showed that $(83.60 \%)$ of the study sample believe that the reality of the administrative control in Al-Awda Hospital in North Gaza Governorate from the point of view of the employees, which is a great agreement.

2. The results showed that the reality of administrative control in Al-Awda Hospital in North Gaza Governorate, according to its relative importance, was as follows:

- The relative weight of the total section of the organizational structure was $(86.40 \%)$, which is a very large agreement.

- The relative weight of the total performance evaluation section was $(87.20 \%)$, which is a very large agreement.

- The relative weight of the total control tools and means section was $(76.0 \%)$, which is highly agreeable.

- The relative weight of the total section of the requirements to achieve the effectiveness of administrative control reached $(84.60 \%)$, which is a very large agreement.

3. The results of the study revealed that $(80.20 \%)$ of the study sample believe that the level of quality of health services in Al-Awda Hospital in the northern Gaza governorates from the point of view of the workers, which is a great agreement.

4. The results showed that the level of quality of health services in Al-Awda Hospital in North Gaza Governorate, according to their relative importance, was as follows:

- The relative weight of the total tangibility section was $(86.40 \%)$, which is very much in agreement.

- The relative weight of the total dependency section was $(83.40 \%)$, which is of great agreement.

- The relative weight of the total response section was $(78.40 \%)$, which is of great agreement.

- The relative weight of the total section of empathy was (81.00\%), which is highly agreeable.

- The relative weight of the total safety axle was $(72.00 \%)$, which is of great agreement.

5. The results of the first hypothesis showed that there was a statistically significant relationship at the level of significance $(\alpha \leq 0.05)$ between the dimensions of administrative control and improving the quality of health service in Al-Awda Hospital in North Gaza Governorate, where the correlation coefficient was (0.509).

As for the results of the sub-hypotheses of the first hypothesis, they were as follows:

- There is a statistically significant relationship between the dimension of the organizational structure as one of the dimensions of administrative control and improving the quality of health services in Al-Awda Hospital. The correlation coefficient was (0.340) and the statistical significance was $\left(0.008^{*}\right)$, which is less than $(0.05)$.

- There is a statistically significant relationship between the performance evaluation dimension as one of the dimensions of administrative control and improving the quality of health services in Al-Awda Hospital. The correlation coefficient was (0.402) and the statistical significance was $\left(0.001^{\star}\right)$, which is less than $(0.05)$.

- There is a statistically significant relationship between the dimension of monitoring tools and means as one of the dimensions of administrative control and improving the quality of health services in Al-Awda Hospital. The correlation coefficient was (0.256) and the statistical significance was $\left(0.048^{* *}\right)$, which is less than $(0.05)$.
- There is a statistically significant relationship between the dimension of requirements for achieving the effectiveness of administrative control as one of the dimensions of administrative control and improving the quality of health services in Al-Awda Hospital. The correlation coefficient was (0.273) and the statistical significance was $\left(0.035^{\star *}\right)$, which is less than $(0.05)$.

6. The results of the second hypothesis showed that there was a statistically significant effect at the level of significance $(\alpha \leq 0.05)$ between the dimensions of administrative control (organizational structure, performance evaluation, monitoring tools and means, requirements to achieve the effectiveness of administrative control) on improving the quality of health services in Al-Awda Hospital.

\section{Recommendations}

In light of the theoretical framework of the study, and the results that resulted from it, the researchers make the following recommendations:

- The need for the senior management in Al-Awda Hospital to pay attention to all dimensions of administrative control, and the elements that contribute to improving the quality of health services, the results of which showed their importance, and their impact on improving the quality of health services at Al-Awda Hospital.

- Raising the level of efficiency of the hospital administration in the practice of administrative control, and that its objective is to detect deviations with the aim of improvement and not to punish employees.

- Building an institutional organizational culture to provide employees with good values and behavioral habits which act as self-monitoring tools on their performance.

- Establishing the internal control unit and providing it with efficient human and material resources to carry out its work efficiently and effectively.

- The necessity of spreading awareness of the importance of oversight work and the quality of health services through holding training courses and specialized educational seminars.

- $\quad$ Facilitate and simplify work procedures and the process of providing health service in order to improve the quality of health service in the hospital.

- Paying attention to the problems of patients and beneficiaries and responding to their desired requirements, as well as listening to their views on the service provision process and identifying the obstacles they face and ways to develop them.

- The necessity of promoting the application of the dimensions of the quality of health services, which is one of the most important matters of competition in the Domain of hospital work, through the decisions issued to implement the dimensions of the quality of health services.

- $\quad$ The necessity of educating the hospital staff to pay more attention to providing the service on time without any delay, working to ensure that patient records are free of errors, and speeding up the treatment of patient complaints without delay.

- Providing the hospital with qualified and trained human resources, in addition to providing it with medical and laboratory equipment and supplies that meet the needs of patients and employees. 


\section{References}

[1] Abdelkader, Mohamed (2015). Measuring the quality of health services in government hospitals in Sudan from the point of view of patients and auditors: a Domain study on major teaching hospitals in the state of Khartoum, The Jordanian Journal of Business Administration, Jordan, 11 (4).

[2] Abu Al-Nasr, Medhat (2008). Total Quality Management, Cairo, Arab Nile Group for Publishing and Distribution.

[3] Abu Amuna, Y. M., et al. (2017). "The Role of Knowledge-Based Computerized Management Information Systems in the Administrative Decision-Making Process." International Journal of Information Technology and Electrical Engineering 6(2): 1-9.

[4] Abu Hashem, Muhammad (2014). The supervisory role of the Ministry of National Economy on imports of foodstuffs, unpublished master's thesis, Islamic University, Gaza, Palestine.

[5] Abu Salmi, Abdullah, and Abbas, Ali (2016). Administrative control in a timely manner and its impact on improving the quality of performance: a Domain study in the health sector in Jordan, Journal of the Faculty of Economics, Management and Commercial Sciences, Algeria, (16).

[6] Abu Sultan, Y. S. A., et al. (2018). "Effect of the Dominant Pattern of Leadership on the Nature of the Work of Administrative Staff at Al-Aqsa University." International Journal of Academic Information Systems Research (IJAISR) 2(7): 8-29.

[7] Abu Sultan, Y. S. A., et al. (2018). "The Style of Leadership and Its Role in Determining the Pattern of Administrative Communication in Universities-Islamic University of Gaza as a Model." International Journal of Academic Management Science Research (IJAMSR) 2(6): 26-42.

[8] Abu-Nahel, Z. O., et al. (2020). "Flexibility of Information and Its Relationship to Improving the Quality of Service." International Journal of Engineering and Information Systems (IJEAIS) 4(8):

[17] Al Shobaki, M. J. (2019). The Role of Decision Support Systems in Reengineering the Academic and Administrative Systems within Universities: A Field Study Applied on Palestinian Universities in Gaza Strip, PHD Dissertation, Suez Canal University, Egypt.

[18] Al Shobaki, M. J. (2019). The Role of Decision Support Systems in Re-engineering the Academic and Administrative Systems within Universities: A Field Study Applied on Palestinian Universities in Gaza Strip, PhD Dissertation, Suez Canal University, Egypt.

[19] Al Shobaki, M. J. and S. S. Abu-Naser (2017). "The Requirements of Computerized Management Information Systems and Their Role in Improving the Quality of Administrative Decisions in the Palestinian Ministry of Education and Higher Education." International Journal of Academic Pedagogical Research (IJAPR) 6(6): 7-35.

[20] Al Shobaki, M. J., et al. (2017). "Importance Degree of eHRM and its Impact on Various Administrative Levels in Palestinian Universities." International Journal of Engineering and Information Systems (IJEAIS) 1(7): 181-196.

[21] Al Shobaki, M. J., et al. (2018). "The Level of Organizational Climate Prevailing In Palestinian Universities from the Perspective of Administrative Staff." International Journal of Academic Management Science Research (IJAMSR) 2(5): 33-58.

[22] Al Shobaki, M., et al. (2018). "Performance Reality of Administrative Staff in Palestinian Universities." International Journal of Academic Information Systems Research (IJAISR) 2(4): 1-17.

[23] Al-Anazi, Adel (2014). The impact of adherence to the timing of administrative control applications and the balanced scorecard on improving the quality of performance: An empirical study on the National Electric Power Company in Jordan, unpublished master's thesis, Middle East University, Amman, Jordan.

[24] Alayoubi, M. M., et al. (2020). "Strategic Leadership Practices and their Relationship to Improving the Quality of Educational Service in Palestinian Universities." International Journal of Business Marketing and Management (IJBMM) 5(3): 11-26.

[25] Al-Dulaimi, Rida (2005). The Impact of Hospital Re-Business on Health Service Quality, Unpublished Master's Thesis, College of
214-234.

[9] Abu-Nahel, Z. O., et al. (2020). "Human Resource Flexibility and Its Relationship to Improving the Quality of Services." International Journal of Information Systems Research (IJAISR) 4(8): 23-44.

[10] Abu-Nahel, Z. O., et al. (2020). "Proactive Flexibility and Its Impact on Improving the Quality of Services in Hospitals." International Journal of Academic Information Systems Research (IJAISR) 4(9): 19-44.

[11] Abu-Nahel, Z. O., et al. (2020). "Quality of Service in NonGovernmental Hospitals in Gaza Strip between Reality and Expectations." International Journal of Academic Information Systems Research (IJAISR) 4(7): 18-36.

[12] Abu-Nahel, Z. O., et al. (2020). "Quality of Services and Its Role in Enhancing Strategic Flexibility in Non-Governmental Hospitals." International Journal of Academic Accounting, Finance \& Management Research (IJAAFMR) 4(10): 38-56.

[13] Abu-Nahel, Z. O., et al. (2020). "Responsive Flexibility and Its Role in Improving Service Quality in Non-Governmental Hospitals." International Journal of Academic Accounting, Finance \& Management Research (IJAAFMR) 4(9): 38-61.

[14] Abu-Nahel, Z. O., et al. (2020). "Strategic Flexibility and Its Relationship to the Level of Quality of Services Provided in NonGovernmental Hospitals." International Journal of Academic Multidisciplinary Research (IJAMR) 4(10): 57-84.

[15] Ahmad, H. R., et al. (2018). "Information Technology Role in Determining Communication Style Prevalent Among Al-Azhar University Administrative Staff." International Journal of Information Technology and Electrical Engineering ` 7(4): 21-43.

[16] Al Shobaki, M. J. (2017). "The Impact of the Dimensions of the Administrative Decision Support Systems on the Re-engineering of the Systems of the Palestinian universities in Gaza Strip from the Employees' Perspective." The Arab Journal for Quality Assurance in Higher Education 10(30): 159-179.

Administration and Economics, University of Mosul, Iraq

[26] Al-Habil, W. I., et al. (2017). "The Impact of the Quality of Banking Services on Improving the Marketing Performance of Banks in Gaza Governorates from the Point of View of Their Employees." 1(7): 197-217.

[27] Alhelou, E. M. S., et al. (2017). "The Quality of Banking Services as an Input to Improve the Marketing Performance of Banks in Gaza Governorates from the Point of View of Customers." International Journal of Information Technology and Electrical Engineering 6(6): 45-58.

[28] Al-Hila, A. A., et al. (2017). "The Quality of Banking Services in Light of the Financial Transformations and Their Impact on the Marketing Performance of the Banks in Gaza Strip." International Journal of Engineering and Information Systems (IJEAIS) 1(8): 3657.

[29] Al-Jerjawi, Ziad (2010). Methodological rules for constructing the questionnaire, 2nd ed., Gaza, Ibn Al-Jarrah Press.

[30] Al-Qaryouti, Muhammad Qasim (2010). Organization and Organization Theory, 4th edition, Amman, Dar Wael for Publishing and Distribution.

[31] Al-Saadi, Raad, and Al-Rubaie, Bushra (2021). The effect of the $5 S$ methodology in improving the quality of health service: an analytical study of the opinions of a sample of doctors and medical staff at Imam Al-Hussein Teaching Hospital in Dhi Qar, Al-Danair Journal, Iraq, 1(23).

[32] Al-Tai, Youssef (2009). The strategic role of total quality management in managing customer relations, Amman, Al-Warraq Publishing and Distribution Corporation.

[33] Al-Zaher, Naim (2010). Fundamentals of Management: Modern Principles and Applications, Amman, the modern world of books.

[34] Ammar, T. M., et al. (2018). "Evaluation and Follow-Up and Their Relationship to the Level of Administrative Transparency in the Palestinian Universities." International Journal of Academic and Applied Research (IJAAR) 2(2): 30-44.

[35] Arqawi, S., et al. (2020). "Integration of the Dimensions of Computerized Health Information Systems and Their Role in Improving Administrative Performance in Al-Shifa Medical 
Complex." Journal of Theoretical and Applied Information Technology 98(06): 1087-1119.

[36] Atta, Olfat (2011). The effectiveness of applying the health service quality measure on external customer satisfaction - patients, The Scientific Journal of Economics and Trade, Egypt, (2).

[37] Bashiwa, Lahn, and Al-Barawi, Nizar (2011). Quality management is an introduction to excellence and leadership, Amman, Dar AlWarraq for Publishing and Distribution.

[38] Bergerum, C., Thor, J., Josefsson, K., \& Wolmesjö, M. (2019). How might patient involvement in healthcare quality improvement efforts work-A realist literature review. Health Expectations, 22(5), 952-964.

[39] D'Cunha, S., \& Suresh, S. (2015). The measurement of service quality

healthcare: a study in a selected hospital, International Journal of Health Sciences and Research, 5 (7), 333-345.

[40] Derry, Zaher (2011). Administrative Control, Amman, Dar Osama for Publishing and Distribution.

[41] Dora, Omar, Gharib, Moaz, Saeed, Salem (2018). Evaluating the quality of health services from the patients' point of view: a comparative study between public and private hospitals, Journal of Economic and Administrative Sciences, University of Baghdad, 24 (105).

[42] El Shobaky, A. M., et al. (2020). "Job Engagement level Among the Administrative Employees in Palestinian Universities." International Journal of Academic Information Systems Research (IJAISR) 4(10): 18-33.

[43] El Shobaky, A. M., et al. (2020). "Psychological Capital and Its Relationship to the Sense of Vitality among Administrative Employees in Universities." International Journal of Academic Accounting, Finance \& Management Research (IJAAFMR) 4(10): 69-86.

[44] El Talla, S. A., et al. (2018). "The Reality of Applying Leadership Standard in Palestinian Universities According to the International Quality Models." International Journal of Academic Management Science Research (IJAMSR) 2(9): 73-82.

[45] El Talla, S. A., et al. (2018). "The Reality of Applying the Policy and Strategy Standard in the Palestinian Universities According to the International Quality Models." International Journal of Engineering and Information Systems (IJEAIS) 2(9): 1-9.

[46] FarajAllah, A. M., et al. (2018). "Participation of Administrative Staff in Decision-Making and Their Relation to the Nature of Work in Universities." International Journal of Academic Multidisciplinary Research (IJAMR) 2(7): 13-34.

[47] FarajAllah, A. M., et al. (2018). "The Impact of the Leadership Standard in International Quality Models on Improving University Performance through the Intermediate Role of the Strategy Standard." International Journal of Engineering and Information Systems (IJEAIS) 2(9): 21-32.

[48] FarajAllah, A. M., et al. (2019). "Measuring the Dominant Pattern of Leadership and Its Relation to the Functional Performance of Administrative Staff in Palestinian Universities." International Journal of Information Technology and Electrical Engineering 7(5): 13-34.

[49] Hamza, Ahmed Ibrahim (2013). Administration in Social Work, Cairo, University Book Distribution Center.

[50] Hassan, Marah (2016). Administrative control and its relationship to job performance, an unpublished master's thesis, An-Najah National University, Nablus, Palestine.

[51] Javed, S. A., Liu, S., Mahmoudi, A., \& Nawaz, M. (2019). Patients' satisfaction and public and private sectors' health care service quality in Pakistan: Application of grey decision analysis approaches. The International journal of health planning and management, 34 (1), 168-182.

[52] Madi, S. A., et al. (2018). "The dominant pattern of leadership and Its Relation to the Extent of Participation of Administrative Staff in Decision-Making in Palestinian Universities." International Journal of Academic Management Science Research (IJAMSR) 2(7): 2043.

[53] Mala, H.M., Ahmed, B.S., \& Sadq, Z.M. (2017). Organizational Institutional Effectiveness through Transformational Leadership,
Qalaai Zanist Journal, 2(3), 128-150.

[54] Manzi, A., Nyirazinyoye, L., Ntaganira, J., Magge, H., Bigirimana, E., Mukanzabikeshimana, L., \& Hedt-Gauthier, B. (2018). Beyond coverage: improving the quality of antenatal care delivery through integrated mentorship and quality improvement at health centers in rural Rwanda. BMC health services research, 18(1), 136.

[55] Mohamed, Abdel Latif (2019). Monitoring performance and improving the quality of health care services by applying to Shubra General Hospital (Kitchener), Journal of the College of Social Work for Social Studies and Research, Fayoum University, (14).

[56] Msallam, A. A., et al. (2020). "Management with Facts and Its Relationship to Quality of Career in University Colleges." International Journal of Academic Management Science Research (IJAMSR) 4(9): 12-34.

[57] Msallam, A. A., et al. (2020). "The Effect of Total Quality Management in Achieving the Requirements of Quality of Career among University Colleges Employees." 4(10): 45-65.

[58] Msallam, A. A., et al. (2020). "The Level of Achieving Job Quality in Palestinian University Colleges." International Journal of Academic and Applied Research (IJAAR) 4(8): 70-90.

[59] Msallam, A. A., et al. (2020). "The Reality of Achieving the Requirements of Total Quality Management in University Colleges." International Journal of Academic Management Science Research (IJAMSR) 4(8): 67-90.

[60] Omar, Nasreen (2014). The impact of administrative control systems on improving the quality of health services: a Domain study in Al-Bashir Hospital, unpublished master's thesis, Middle East University, Amman, Jordan.

[61] Pakurár, M., Haddad, H., Nagy, J., Popp, J., \& Oláh, J. (2019). The service quality dimensions that affect customer satisfaction in the Jordanian banking sector. Sustainability, 11 (4), 1-24.

[62] Salama, A. A., et al. (2018). "The Role of Administrative Procedures and Regulations in Enhancing the Performance of The Educational Institutions-The Islamic University in Gaza is A Model." International Journal of Academic Multidisciplinary Research (IJAMR) 2(2): 14-27.

[63] Sedky, Ahmed, and Hamoudi, Lina (2017). Measuring the dimensions of health service quality provided in Aleppo governmental hospitals: a comparative study, Al-Quds Open University Journal for Administrative and Economic Research, $p$ (9).

[64] Shobaki, M. J., et al. (2017). "The impact of the administrative dimensions of the decision support systems in the re-engineering of the Palestinian universities in Gaza Strip from the standpoint of employees." 10(2017).

[65] Shuichi, N (2014) The Role of Middle and Management Control System in Healthcare-A Case Study of a Middle Class Hospital, Journal of Japanese Association for Health Care Administrators, 8(1), 8-29.

[66] Singh, N., (2011). Human Resource Management, Published by USP/Laxmi Publications (P) Ltd, New Delhi.

[67] Snowdon, A, \& Karin, S, (2012). Measuring What Matters: The Cost vs. Values of Health Care, Research Analyst, International Centre for Health Innovation Richard Ivey School of Business, Western University.

[68] Zaid, A. A., et al. (2020). "The Impact of Total Quality Management and Perceived Service Quality on Patient Satisfaction and Behavior Intention in Palestinian Healthcare Organizations." Technology Reports of Kansai University 62(03): 221-232.

[69] Zaqout, I., et al. (2018). "Information Technology used and its Impact on the Participation of Administrative Staff in DecisionMaking in Palestinian Universities." International Journal of Academic Multidisciplinary Research (IJAMR) 2(8): 7-26. 